\section{Birlesik Dünya Arastrma Cypriot Journal of Educational BD-CENTER \\ Sciences}

Innovasyon ve Yayıneılık Merkezi
Volume 15, Issue 3, (2020) 423-432

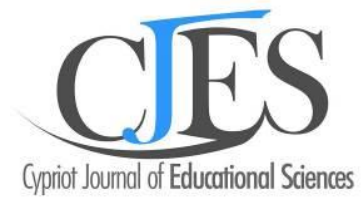

$\underline{\text { www.cjes.eu }}$

\title{
Fulfilment of personal potential by high school graduates in time of career choice
}

Evgenya S. Romanova, Moscow City University, 4/1, 2nd Agricultural passage, Moscow, 129226, Russian Federation ORCID ID 0000-0002-9032-6869.

Ludmila I. Bershedova, Moscow City University, 4/1, 2nd Agricultural passage, Moscow, 129226, Russian Federation ORCID ID 0000-0002-8567-9950.

Svetlana N. Tolstikova *, Moscow City University, 4/1, 2nd Agricultural passage, Moscow, 129226, Russian Federation ORCID ID 0000-0001-8441-0776.

Elina N. Rychikhina, Moscow City University, 4/1, 2nd Agricultural passage, Moscow, 129226, Russian Federation ORCID ID 0000-0003-2146-574X.

Tatiana Yu. Morozova, Moscow City University, 4/1, 2nd Agricultural passage, Moscow, 129226, Russian Federation ORCID ID 0000-0002-9044-4988.

\section{Suggested Citation:}

Romanova E.S., Bershedova L.I., Tolstikova S.N., Rychikhina E.N., \& Morozova T.Y. (2020). Fulfilment of Personal Potential by High School Graduates in Time of Career Choice. Cypriot Journal of Educational Science. 15(3), 423-432. DOI: 10.18844/cjes.v\%vi\%i.4908

Received from October 3, 2019; revised from February 20,2020; accepted from June 30, 2020. (C2020 Birlesik Dunya Yenilik Arastirma ve Yayincilik Merkezi. All rights reserved.

\begin{abstract}
The paper presents results of the desktop analysis on the current status of the problem of the personal potential in terms of psychology. It provides the author's understanding of the term as the formation consistent and structured in its psychological aspect. This is the analysis of the characteristics that the career choice has and the difficulties that the graduates face in this process. We believe that substantial resources for the independent and responsible career choice are inherent in the personal potential. According to the research methods, the structure of the personal potential includes intra and interpsychological characteristics. Internal factors relate to the non-acceptance of the choice situation, the lack of skills that are necessary for subjective construction of its process. They also come from hesitation, lack of confidence, poor selfconcept, internal conflicts, low community commitment, etc. In most cases, the powerful influence of relevant adults is an external obstacle. The data obtained justify a need in psychological and education counseling to develop the personal potential of graduates. In this regard, one of the main tasks is to provide graduates with competent and comprehensive support to overcome difficulties in the process of making the career choice and personal potential development.
\end{abstract}

Keywords: personal potential, career choice, person's social resources, individual opportunities, commitment of graduates, self-control resources;

\footnotetext{
* ADDRESS FOR CORRESPONDENCE: Svetlana N. Tolstikova, Moscow City University, 4/1, 2nd Agricultural passage, Moscow, 129226, Russian Federation

E-mail address: TolstikovaSN@mail.ru / Tel.: +7 (499) 181-24-62
} 
Romanova E.S., Bershedova L.I., Tolstikova S.N., Rychikhina E.N., \& Morozova T.Y. (2020). Fulfilment of Personal Potential by High School Graduates in Time of Career Choice. Cypriot Journal of Educational Science. 15(3), 423-432, DOI: 10.18844/cjes.v\%vi\%i.4908

\section{Introduction}

The today's rapidly changing world imposes a wide range of qualitatively new claims to an individual, his/her ability to overcome constantly arising challenges and unforeseen life circumstances. In terms of this new social reality, the problem of individual's internal reserves (not so much necessary, as possible) is pressing. The way the question is put evidences that we are talking about the specific psychology-related formation that scientists call the personal potential. They think that the personal potential refers to the idea of the "changing personality in the changing world" (Asmolov, 1990). It manifests itself in specific activities of the individual based on the resistance to difficulties and flexible behaviour in the changing circumstances (Alcalde \& Nagel, 2016). Broadly speaking, individual's potential capabilities are the force on which the effectiveness of activities depends, as well as self-actualization and self-fulfilment, which is an undeniable value for every person in all spheres of the life.

As a psychological phenomenon, the personal potential does not appear as arbitrium. We might find its sources and prerequisites in high school students as far as kids open up new life prospects when the reality goes beyond the boundaries of practice and direct communication. Researchers and education practitioners describe the personal potential as an essential result of the contemporary education (Aithal \& Suresh Kumar, 2016; Varzhapetyan et al., 2019, p. 12).

The end of high school studies is one of the most challenging and crucial moments in lives of young people. Career-oriented personal identification and the career choice are a psychological centre in the social situation of the graduates' development. Making the informed career choice directly relates to the personal potential of the young people as an internal resource that specifies the independence of their actions in terms of uncertainty, activity focus and responsibility degree for choice and decision consequences. The purpose of this research is to consider specifics of the personal potential of high school graduates in the situation when they make the career choice. Achievement of this goal assumes the identification of the content-related framework of the personal potential as a psychological formation and the analysis of its specifics in high school graduates in the situation when they make the career choice.

\section{Literature review}

The word potential has the major content-related charge in the definition of the personal potential. With all the variety of available definitions of the potential, there are the trends common to all approaches to the definition of this concept. Followers of the mentioned approaches think that the potential is in the indissoluble unity with the concept of the possibility as a hidden resource and source. They define it as the strength that makes it possible to show one's possibilities in certain conditions and regard it as the readiness of an individual to career-related activities. The content of the potential as a psychology-related phenomenon depends on the hidden possibilities of an individual showing his/her objectives, values, senses, and motivations. The true essence of the potential is only clear through career-related activities, in the transition to career-related activities and self-actualization in them.

The concept of the personal potential as an academic category was established in papers on the problem of the personal potential (capital) (Calhoun \& Tedeschi, 2006; Luthans et al., 2007; Korsakiene et al., 2011). In academic circles, this was discussed in humanistic psychology. According to its representatives, each person has the human potential, the development process of which is associated with the personal advancement, self-fulfilment, self-actualization, and full-fledged functioning of the human being (Maslow, 1999). The degree of the potential achievement depends on 
individual differences and personal maturity (Rogers, 1994; Maslow, 1999). Gagné \& Deci (2005), Carver \& Connor-Smith (2010), Caprara \& Steca (2006), Bedi \&Brown (2005), Maddi et al. (2007), Maddi (2008), and Rogers (1994) describe in detail the separate dimensions of the personal potential, such as the ego power, locus of control, vitality, will, self-identity, internal backbone, optimism, coping, focus on action, and self-efficacy. They have established that potentialities of an individual are much wider than the real ones. Moreover, in the life process, the individual gets only a part of his/her resources materialized.

Researches refer the personal potential to the complex system of properties of the personality, the multi-dimensional resource that develops under an influence of objective and subjective factors. The psychological content of the personal potential includes three interacting aspects, i.e. sustainable, dynamic, and result oriented. Sustainable is about characteristics of the personality that make it possible for an individual to maintain internal sustainability and balance. The dynamic aspect covers the capacities for self-development, flexibility, and self-adjustment. The result-oriented aspect relates to the quality of personal self-fulfilment, the intensity of the career-related activities that the person performs and readiness for whatever changes in life situations and activities.

The self-determination phenomenon is the highest form, with which the personal potential manifests itself. Owing to this, possibilities are transformed into the reality, real actions, decisions, choices, and deeds. In terms of self-control functions, the personal potential represents resources for establishment of goals, goal achievement, and coping with adverse life circumstances (Leontiev, 2011).

The understanding of the potential in terms of the progressive development of the personality is typical for most papers on this issue. To some extent, fathers of Russian psychology established this approach. The idea of the potential is embodied in the concept by Vygotsky, his concept of the zone of proximal development, which acts as the development potential and the possible growth of a child. Vygotsky (1983) believes that the transition from a current state of development to the zone of proximal development depends on the maturity of the corresponding age-specific inner structures and functions that together are necessary prerequisites for the child readiness for the transition. The development is the process during which they accumulate the certain potential. In the proactive creative work, the fulfilment of far-reaching possibilities of human beings is the most important personality and identity indicator (Ananiev, 1968).

The school time is the time of intensive deployment and disclosure of the personal potential of high school students. As far as individual capabilities develop, with the progressive development of the personality and subjectivity, boundaries of something that is possible in the personal field of high school students expand, are transformed and structured. At each training stage, certain conditions appear required for the establishment of the personal potential, making their contribution to the holistic and continuous process of its development.

The developed personal potential correlates with the personal maturity and shows the individual's capabilities to overcome and change various life circumstances. In the situations that differ by uncertainty and complexity, the personal potential has specific forms of manifestation. At the final stage of high school training, the problem of the real and conscious career self-determination becomes central. It is internally based on the career choice. At this age, choosing is extremely controversial and challenging. This is because it goes far beyond the boundaries of the present and relates to targets set for the future, awareness of achievement techniques, as well as taking one's own responsibility for the achievement. Making the first independent choice, a young person decides how 
to build the future life in general, decides whom and which to be. Due to the complexity of this fateful choice, as well as poor life experience, the career choice situation becomes complicated. Essential resources for challenge overcoming and making the informed, independent, and responsible career choice depend on the personal potential of high school graduates.

\section{Material and Methods}

The personal potential is a complex phenomenon in the theoretical sense, described as a holistic and organized system. This system is relevant to the problems of successful performance in the changing life environment, complicated choice situations, in terms of infeasibility, and uncertainty. Thus, the synergistic interaction between structural components in the personal potential, instead of being merely mechanistic, is much more complicated by nature. This predefines the methodology following which we explore this psychological phenomenon.

The research lies on the certain methodological approaches that mirror the content, algorithm and focus of research on the personal potential that high school graduates have. The system approach derives from the idea of the personal potential as a complex structured formation, the content of which includes the integral set of properties, components, and relationship. This makes it possible to evaluate it as a system. Interpreting the personal potential of high school students as an element of the micro-, meso- and macro-system allows comprehending the specific features of its formation and development in the social environment and educational space. This implies that examining the personal potential is an integral part of studying the conditions under which it functions and the multiplicity of the relations in which it appears (Lomov, 1984).

The process-dynamic approach explains the specifics that the personal potential has when it functions, both in time and in the various life situations described with certain challenges. This approach broadens the understanding of transformations and personal potential realization at all its levels - psychological, social, and the level of self-regulation in the system of interaction with the outside world (Antsyferova, 2006).

The activity approach provides the understanding of the personal potential development during the activity that is a root cause of its qualitative, functional, dynamic, and structural transformations. In this case, as Leontiev (1997) puts it, the central role is attributed to the main occupation of high school students which underlies their comprehensive activities, personal meaning and performance. Within the framework of the main occupation, the properties and qualities of students' capabilities are integrated and modified, as well as the spheres of educational, social, and public life expand. The activity approach allows diversifying the forms and content of pedagogical work.

The subjective approach determines the initiation of various forms of inner and external activities of high school students, the coordination between goal choices and own capabilities in communication, activities, behaviour, their control, focus, and content. The subject approach displays the attitude to high school students as a subject of the personal potential that implement their opportunities through coordinating their goals and individual resources. Developing a student in this avenue involves the psychological and pedagogical work focused on stimulation of various internal and external activities that regulate young people's subjective attitude to themselves, the general public, and the world (Brushlinsky, 1996). 
Romanova E.S., Bershedova L.I., Tolstikova S.N., Rychikhina E.N., \& Morozova T.Y. (2020). Fulfilment of Personal Potential by High School Graduates in Time of Career Choice. Cypriot Journal of Educational Science. 15(3), 423-432, DOI: 10.18844/cjes.v\%vi\%i.4908

\section{Results and Discussion}

In terms of the content, we referred the students' personal potential to the dynamic and systematic formation in terms of its psychological aspect. We think that the structure of the personal potential includes intra and interpsychological characteristics, as well as the self-control resources that together mirror age-specific and mental capabilities of students. The degree, to which they achieve their personal self-fulfillment, depends on their own proactive behaviour. All components of the personal potential are in interaction, their coordination and integral unity determine a value of the personal potential as an important determinant in activities, communication, and behaviour of high school students.

Intrapsychological characteristics represent mature and internally organized sustainable individual properties of a person that together mirror his/her inner world and constitute an integral whole of opportunities.

Dominating intrapsychological characteristics are the properties that are identity attributes. Selfconception represents a wide spectrum of ideas of oneself, plays a specific role in activities of an individual, aimed at self-fulfilment. Self-efficacy as a belief in one's own strengths and opportunities relates to perseverance, insistence, optimism, the manifestation of which predetermines the achievement of more significant learning results. Reflexivity is a framework trait of the personality, aimed at self-learning, learning of the inner world in all its aspects. Owing to reflexivity a human being takes control over own activities. The human being becomes an author of his/her own life.

Value and semantic characteristics together predetermine a temper as an independent system of sustainable personal traits, subjective attitudes towards people, the world, community, and oneself represented in behaviours, actions, and communication. As a core of the personal potential, these characteristics establish inner sustainable reference points in terms of the changing living environment. Personality orientations of high school students mirror their readiness for activities, and, in terms of functions, predefine successful self-fulfilment.

Intrapsyhological characteristics of an individual as established formations in the individual take control over the process of personal potential functioning and make it possible to keep sustainability in terms of changes and uncertainty (Karpenko et al., 2019).

Interpsychological characteristics mirror the certain qualities of students as actors in their activities, communication, and behaviours. National psychology refers the concept of the subject to the highest level of individual activities of a person, his/her autonomy, purpose-orientation, proactiveness, and creativity towards his/her life. The subject component naturally accumulates the properties of the human being as an individual and person that together predetermine the readiness for activity performance and achievement of the high possible efficiency in these activities.

National psychologists traditionally think that the activity is crucial in the personality development. The activity determines a real connection of the subject with the reality, and within the framework of available capabilities, it creates the conditions for the development of wider potentialities. The activity vector sets a goal and motive, where the goal as a phenomenon of the proactive reflection that designs the activity, while the motive encourages it. Goal-setting capabilities of the subject say that (s)he has the ideas of his/her capabilities. The characteristics of an actor in the personal potential structure determine a degree and intensity of the individual's activity.

For successful self-fulfilment it is important to have the capacities for effective interaction and communication, skills of orientation in the advanced social situation. The complex and multifaceted 
nature of the behaver's activity is an indicator of the situation-individual interaction, in the framework of which people follow various strategies to achieve certain goals, aspirations, and opportunities. Strategic planning of behaviour accumulates the will, interests, motives, and needs in the personal potential structure.

Interpsychological characteristics of the personal potential are attributes of the built-in, informed, and independent activity of high school students expanding boundaries of their capacities. This facet of the personal potential is substantial to achieve the activity-based implementation and overcome choice and conflict situations.

Potentials of self-control and self-fulfilment are central to the structural organization of the personal potential. The multifaceted system of the informed self-control is a universal means in the development of basic forms of the efficient human activity, implementation and mobilization of all the psychological resources in difficult cases. Self-control correlates with intra and interpsychological characteristics of the personal potential and ensures the orientation in the community environment, as well as the full-fledged situation-based interaction with it. Self-control functions are personal identity, self-fulfilment, and self-determination.

In self-determination, the personal is manifested in the personality, the need in external assistance is overcome, the person develops an ability to rely only on him/herself, gets the sense of the boundary between the world and oneself. The subject now perceives a semantic sphere as a voice of the inner necessity (Buyakas, 2002; Nikitina et al., 2015]. Self-fulfilment is interpreted as the process in which the individual reveals and uses own capabilities. Self-determination and self-fulfilment sequentially follow each other and mirror various phases in the individual-world interaction. The highest form of the self-control system is self-determination of the individual, the main in which is informed organization of one's own life and a search for one's own place in the life. Self- determination is the most complex mechanism in self-control as the transformation of opportunities into facts depends on self-determined choices made by the subject and his/her independent decisions. The elaboration, development, and formation of the self-control system determine the logic in the development of the personal potential and its characteristics. The interaction between all the systems in the self-control helps to overcome problem situations in communication, behaviour, and activities.

The entity of the highlighted structural components makes the personal potential to be systematic. The personal potential of students in establishments of general education is a multidimensional formation with unspecific self- control functions. Its maturity determines the development of the personality's possibility characteristics and ensures the readiness for non-standard decisions, situations, actions, and activities.

Alongside this, in a strict sense, it is impossible to consider this structure of the personal potential complete as it does not include social qualities of the personality that define a social dimension, involvement in community relations, in the society. In this context, we are talking about the community potential of the personality. Such the potential combines in its structure two units, i.e. resources of the social environment and social resources of the individual (Doctorovich, 2007).

Environment resources qualify social resource in families, potentials in the educational environment, the chances available in a region as a specific community. Social resources of an individual are characteristics of the community commitment of high school students and specifics of personal (and life) views that students have by integrating elective dominant attitudes towards the world, themself, and people. The personal view determines one's own capabilities and opportunities 
as determinants in their implementation, thus they might by social criteria in evaluation of the personal potential (Fig. 1).

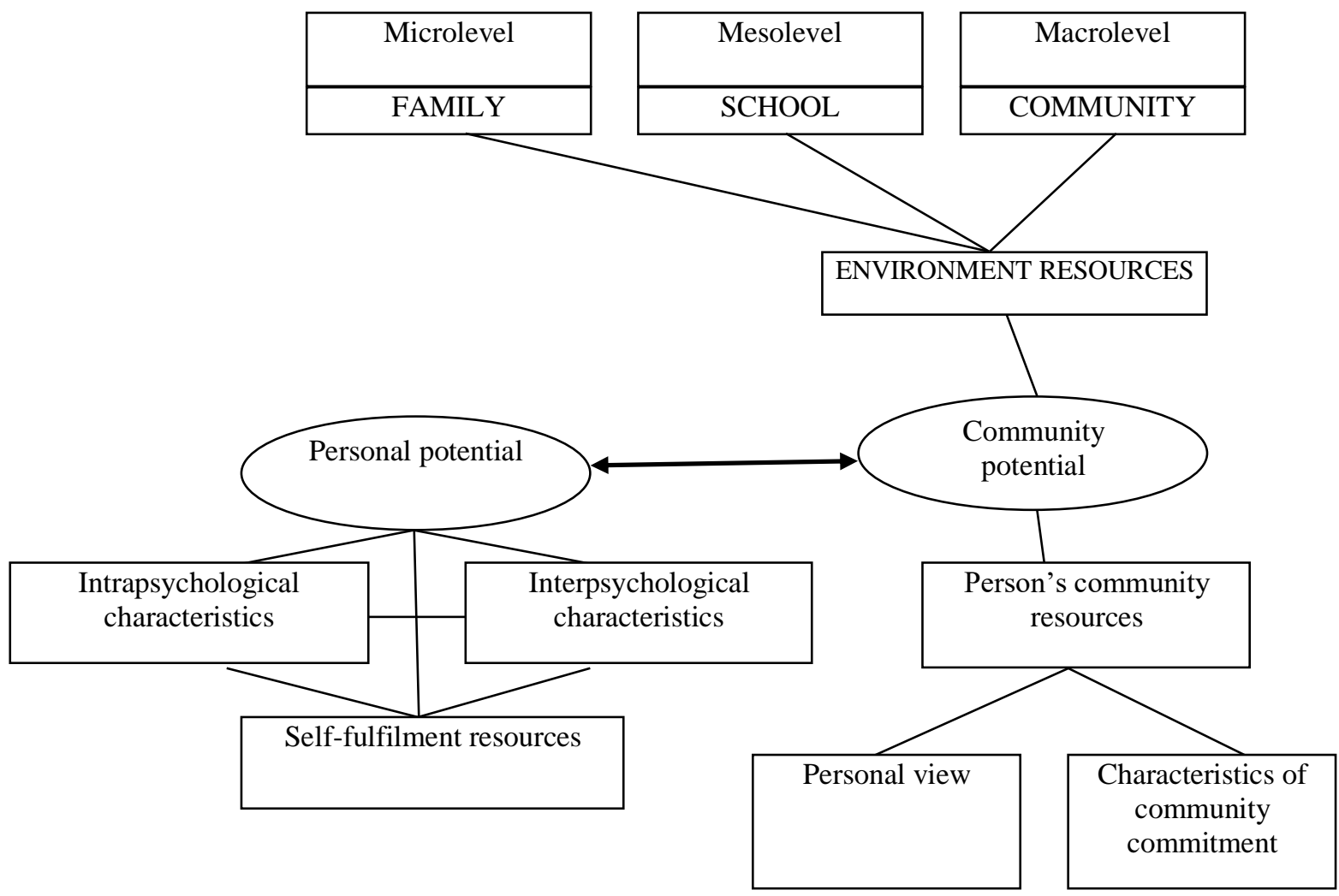

Figure 1. The structure of the personal potential that high school students have

In general, we can state that as a psychological formation, the personal potential of high school students is strongly structured and systemic, including variables of different orders. This assures functioning of the personal potential in certain cases and activities with a wide range of effects. The mature personal potential correlates with the personality maturity of the youth and is a condition of their readiness for the career choice and joining the adult life. The nature, structure, and education level of the population have a direct influence on indicators of the economic growth and society development (Sam, 2018; Menshikov \& Volkova, 2018).

In high school, the career choice is the first adult and independent choice of young people (Deci \& Ryan, 2002). Pertinence and fatefulness of this event, perceived individually, predetermine it as a focal point of life paths of young people when decision making shapes the entire future. The choosing, elaborated as a process in the inner world, substantively includes planning, decision making, awareness, and independence, which implies career planning, creation of criteria for their evaluation, value-semantic comparison of alternatives, and learning of one's own capabilities. This work in the inner world depends on flexibility of self-control mechanisms and has connections with goal setting, targeting, and goal achievement. The most important feature in this choice is that it is an existential deed, an essence of which is acceptance of responsibility for the implementation of a generated solution, "investing of oneself in its implementation" (Leontiev, 2014). 
Real-life career choices have connections with personal vies, the high level of subjectivity and community commitment of young people, their inner awareness, confidence in their own freedom and ability to choose, their good knowledge of available careers. Due to the complexity of its inherent subjective and personal objectives, this process has connections with how young people evaluate their inner resources, understand and discover their capabilities, interests, missions, personality traits, and properties, which are in many respects the basis for strategic and tactical planning and execution of plans. The transfer of certain knowledge and skills, properties and qualities of the personality from a conceivable state to the reality encourages independent behaviour of young people, flexibility in casespecific interactions, awareness, independence, inner confidence, sustainability in terms of uncertainty, and an ability to tolerate external pressures. The disclosure of the personal potential, its adjustment to given situations in many respects assure a full-fledged and qualitative choice. Successful solutions to career choice challenges have a direct relation to maturity of the personal potential and its structural components.

Our data confirm recent findings of many researchers saying that when graduates make the career choice, they face various inner and external difficulties. Inner factors relate to the non-acceptance of the choice situation, a lack of skills required for the subjective construction of its process, available dysfunctional myths, hesitation, uncertainty, poor knowledge of themselves, their own abilities and orientations, personal characteristics, and qualities, inherent conflicts, poor community commitment, etc. The nature of graduates' attitudes towards the choice situation might be complicated by diffuse ideas of their own future, a lack of informative personal career plans, their value-semantic inconsistency, and non-developed self-control processes (Romanova, 2013).

The strong influence made by relevant adults is an external barrier in the most cases. The career choice, not experienced as one's own, guided by parents, professors, and friends might lead to unfavourable psychological consequences in the future. The failed independent career choice is an evidence of the so-called weak internal ramrod, the key characteristics of which are the personal opinion of a graduate, his/her focus on actions, his/her ability to tolerate the pressure and remain stable, self-determination, self-fulfilment, etc. These variables mirror central properties in the structure of the personal potential. Being related to the choice characteristics, they are prerequisites and a psychological basis for the career choice.

The difficulties that the high school graduate face when they make career choice evidence that structural components of their personal potential differ in terms of their successful and equal development. Such differences shape a way for psychological and educational counseling (Romanova et al., 2015; Romanova et al., 2019). Contents and focus of this counseling provided by relevant adults (parents, professors, and psychologists) assume a focus as not so much on a choice result, but on its process, within the framework of which graduates make their independent choice. In these challenging activities, adults should support young people in learning of their own choice, their desire to come from their own identity, their search for personal grounds for decision making, support their independency and possibility of freedom, self-determination and self-fulfilment. In this interaction between adults and high school graduates, properties and qualities of their potential's forces are revealed, updated, integrated, and transformed. The graduates' personal potential creates the unique and inherent environment of opportunities that finally predetermines their readiness for informed, responsible, and independent career choices. 
Romanova E.S., Bershedova L.I., Tolstikova S.N., Rychikhina E.N., \& Morozova T.Y. (2020). Fulfilment of Personal Potential by High School Graduates in Time of Career Choice. Cypriot Journal of Educational Science. 15(3), 423-432, DOI: 10.18844/cjes.v\%vi\%i.4908

\section{Conclusion}

In the research, we aimed at the more comprehensive representation of the problem of the personal potential of graduates, both in its theoretical dimension and in terms of real-life cases. We came from the assumption that it is possible to measure the efficient functioning of the personal potential of graduates in terms of their social situation, for which the career choice is central. Eventually, we understood that in its psychological aspect, the personal potential is a complex structured formation, the components of which manifest themselves in the wide range of situations and define various consequences. The characteristics of the potential ensure personality sustainability under external influences, sustainability of value-semantic focuses, self-control over activities, flexible responses to changes, readiness for overcoming and readiness for changed life circumstances.

The research findings make it possible to conclude that that the identified components in the personal potential have the complex system of interrelationships with choice characteristics and play a significant role in its process. The structure of these interrelationships has been yet waiting for its deeper research. The research results justify the need to consider the personal potential of graduates for successful and appropriate career choices. One of the main tasks in psychological and education counseling that high school staff, professors, and parents have is to provide students with the competent and comprehensive support to overcome difficulties in this process and develop the personal potential.

\section{References}

Aithal, P. S., \& Suresh Kumar, P. M. (2016). Maintaining teacher quality in higher education institutions. Journal of Eurasian Social Dialogue, 1(2), 41-51. Available at SSRN: https://ssrn.com/abstract=2803012

Alcalde, P., \& Nagel, J. (2016). Does active learning improve student performance? A randomized experiment in a Chilean university. Journal of Eurasian Social Dialogue, 1(2), 1-11.

Ananiev, B. G. (1968). Man as the object of cognition. Publishing House of Leningrad University.

Antsyferova, L.I. (2006). Personality development and problems of gerontology. The Publishing House of the Institute of Psychology of the RAS.

Asmolov, A.G. (1990). Psychology of personality. Publishing House of Moscow University.

Bedi, G., Brown, S. (2005). Optimism, coping style and emotional well-being in cardiac patients. British Journal of Health Psychology, 1, 57-70. https://doi.org/10.1348/135910704X15266

Brushlinsky, A.V. (1996). Subject psychology in changing society. Psychological Journal, 1(3), 17-27.

Buyakas, T.M. (2002). The problem and psychotechnics of personal self-identity. Voprosy Psychologii, 2, 28-39.

Calhoun, L. G., Tedeschi, R.G. (Eds.) (2006). Handbook of posttraumatic growth: research and practice. Lawrence Erlbaum.

Caprara, G., Steca, P. (2006). Affective and interpersonal self-regulatory efficacy beliefs as determinants of subjective well-being. In A. Delle Fave (Ed.), Dimensions of well-being. Research and intervention (pp. 120142). Franco Angeli.

Carver, C.S., Connor-Smith, J. (2010). Personality and coping. Annual Review of Psychology, 61, 679-704. https://doi.org/10.1146/annurev.psych.093008.100352

Deci, E. L., Ryan, R.M. (2002). Self-determination research: reflections and future directions. In E.L. Deci \& R.M. Ryan (Eds.), Handbook of self-determination research (pp. 431-441). The University of Rochester Press.

Doctorovich, A.B. (2007). Social potential as a subject of system studies. Russia and the Contemporary World, 3, 179-189.

Gagné, M., Deci, E. L. (2005). Self-determination theory and work motivation. Journal of Organizational Behaviour, 26, 331-362. https://doi.org/10.1002/job.322

Karpenko, L. et al. (2019). Human development in the context of provision of the social safety of society. Journal of Security and Sustainability Issues, 8(4), 727-736. https://doi.org/10.9770/issi.2019.8.4(15) 
Romanova E.S., Bershedova L.I., Tolstikova S.N., Rychikhina E.N., \& Morozova T.Y. (2020). Fulfilment of Personal Potential by High School Graduates in Time of Career Choice. Cypriot Journal of Educational Science. 15(3), 423-432, DOI: 10.18844/cjes.v\%vi\%i.4908

Korsakiene, R., Breivyte, I., \& Wamboye, E. (2011). Sustainable development and human development index. Journal of Security and Sustainability Issues, 1(2), 103-112. https://doi.org/10.9770/jssi.2011.1.2(3)

Leontiev, A.N. (1977). Activity. Consciousness. Personality. Politizdat.

Leontiev, D.A. (2014). Psychology of choice. II. Personality prerequisites of choice and its personality-related consequences. Psychol. Journal, 35(6), 56-68.

Leontiev, D.A. (Ed.). (2011). Personal potential: structure and diagnosis. Smysl.

Lomov, B.F. (1984). Methodological and theoretical problems of psychology. Nauka.

Luthans, F., Youssef, C. M., \& Avolio, B.J. (2007). Psychological capital: Developing the human competitive edge. Oxford University Press. https://doi.org/10.1093/acprof:oso/9780195187526.001.0001

Maddi, S. (2008). The Courage and strategies of hardiness as helpful in growing despite major, disruptive stresses. American Psychologist, 63(6), 563-564. https://doi.org/10.1037/0003-066X.63.6.563

Maddi, S., Harvey, R., Resurreccion, R., Giatras, C., Raganold, S. (2007). Hardiness as a performance enhancer in firefighters. International Journal of Fire Service Leadership and Management, 1, 3-9.

Maslow, A. (1999). New frontiers in human nature. Smysl.

Menshikov, V., \& Volkova, O. (2018). Economic growth and impact of institutions on quality of human capital: A case study. Journal of Security and Sustainability Issues, 8(2), 125-134. https://doi.org/10.9770/JSSI.2018.8.2(11)

Nikitina, N., Komarova, E., and Romanova, E. (2015). Qualimetric methods in the evaluation of the quality of professional training of specialists in social work. Review of European Studies, 7(3), 66-79. https://doi.org/10.5539/res.v7n3p66

Rogers, C. (1994). A look at psychotherapy. The formation of man. Progress.

Romanova, E. S. (2013). Management of career guidance work at high school. Publishing Centre "Academy". Romanova, E.S. et al. (2015). Psychological aspects of the family. Ontoprint.

Romanova, E.S. et al. (2019). Conflictological competence of a teacher as a condition of positive interaction in the educational environment. Revista Espasions, 40(31), p. 29.

Sam, V. (2018). Overeducation among graduates in developing countries: What impact on economic growth? Journal of Eurasian Economic Dialogue, 3(6), 1-19.

Varzhapetyan, A. G., Semenova, E. G., Fomina, A. V, Balashov, V. M., \& Balashova, K. V. (2019). Assessing the quality and effectiveness of additional vocational education. Espacios, 40(2), p. 12.

Vygotsky, L.S. (1983). Collected works: In 6 Vols. Vol. 3. Pedagogics. 